\title{
Metabolizable Energy and Metabolizability Coefficients of Moringa and Bocaiuva for Slow-Growing Broilers at Different Ages
}

\author{
Violeta Andre Macie
}

Faculty of Veterinary Medicine and Animal Science, Federal University of Mato Grosso do

Sul, Campo Grande, Mato Grosso do Sul, Brazil. E-mail: violetamacie@gmail.com

Karina Marcia Ribeiro de Souza Nascimento (Corresponding author)

Faculty of Veterinary Medicine and Animal Science, Federal University of Mato Grosso do

Sul. Av. Senador Filinto Muller, 2443, CEP:79074-460, Campo Grande, MS, Brazil.

E-mail: karina.souza@ufms.br

\section{Charles Kiefer}

Faculty of Veterinary Medicine and Animal Science, Federal University of Mato Grosso do

Sul, Campo Grande, Mato Grosso do Sul, Brazil. E-mail: charles.kiefer@ gmail.com

\author{
Raquel Soares Juliano \\ Embrapa Pantanal. Corumbá, Mato Grosso do Sul, Brazil. \\ E-mail: raquel.juliano@embrapa.br \\ Frederico Olivieri Lisita \\ Embrapa Pantanal. Corumbá, Mato Grosso do Sul, Brazil. \\ E-mail: frederico.lisita@embrapa.br
}

\section{Thiago Rodrigues da Silva}

Faculty of Veterinary Medicine and Animal Science, Federal University of Mato Grosso do Sul, Campo Grande, Mato Grosso do Sul, Brazil. E-mail: thiagoth_rodrigues@ hotmail.com 
Luanna Lopes Paiva Copat

Faculty of Veterinary Medicine and Animal Science, Federal University of Mato Grosso do Sul, Campo Grande, Mato Grosso do Sul, Brazil. E-mail: lu.paiva.lopes@gmail.com

\title{
Natália Ramos Batista Chaves
}

Federal Institute of Mato Grosso, Campus of Alta Floresta. Alta Floresta, Mato Grosso, Brazil. E-mail: natalia.chaves@alf.ifmt.edu.br

\section{Henrique Barbosa de Freitas}

Faculty of Veterinary Medicine and Animal Science, Federal University of Mato Grosso do Sul, Campo Grande, Mato Grosso do Sul, Brazil.

E-mail: henrique_barbosa_7@yahoo.com.br

\section{Maurício Silva Rosa}

Faculty of Veterinary Medicine and Animal Science, Federal University of Mato Grosso do Sul, Campo Grande, Mato Grosso do Sul, Brazil. E-mail: mauriciosilvarosa@ hotmail.com

Received: Dec. 6, 2019

doi:10.5296/jas.v8i3.16559
Accepted: Jan. 20, $2020 \quad$ Published: Feb. 27, 2020

URL: https://doi.org/10.5296/jas.v8i3.16559

\begin{abstract}
This study aimed to determine nutrient metabolizability coefficients and apparent metabolizable energy (AME) and nitrogen-corrected AME (AMEn) values of moringa leaf meal and bocaiuva pulp for slow-growing broilers. Three hundred and fifty 1-day-old chicks of the Red Naked Neck line were allocated to five treatments in a completely randomized design with seven replicates of 10 birds. Treatments consisted of a control diet and four test diets. The proportion of ingredients evaluated in the test diets was $20 \%$ moringa leaf meal and bocaiuva pulp and $40 \%$ corn and soybean meal. The total excreta collection method was applied with $1 \%$ ferric oxide included in the diets as a marker of start and end of collection, in the starter, grower and finisher phases. The metabolizability coefficients of dry matter, crude protein and ether extract and the AME and AMEn values of moringa leaf meal, bocaiuva pulp, corn and soybean meal were determined. Data were subjected to analysis of variance and means were compared by Tukey's test at the 5\% probability level. The protein from moringa leaf meal and the fat from bocaiuva pulp are highly metabolizable by birds at different ages. The AME and AMEn values of moringa leaf meal ranged from 2557 to 2868
\end{abstract}


$\mathrm{Kcal} / \mathrm{kg}$ and 2205 to $2479 \mathrm{Kcal} / \mathrm{kg}$, respectively. In bocaiuva pulp, AME and AMen ranged between 2680 and $3119 \mathrm{Kcal} / \mathrm{kg}$ and 2483 and $2490 \mathrm{Kcal} / \mathrm{kg}$, respectively. Therefore, the alternative ingredients can be used in the formulation of diets for slow-growing broilers to partially replace corn and soybean meal.

Keywords: alternative ingredient, bocaiuva pulp, moringa leaf meal

\section{Introduction}

The main raw materials used in the formulation of poultry diets (corn and soybean meal) directly influence rises in production costs. Thus, the use of alternative sources able to meet the requirements of birds in different rearing phases has been widely researched by nutritionists (Generoso et al. 2008), aiming at reducing such expenses.

However, to formulate nutritionally viable diets, it is essential to know the nutritional value of feedstuffs (Generoso et al. 2008) and the growth and energy metabolism of birds and investigate the factors that affect them as well as the availability and utilization of the other diet nutrients (Sakomura et al. 2004a).

The variable chemical composition of feedstuffs has been a major problem to nutritionists (Generoso et al. 2008), because the nutritional value of those ingredients is related to the soil-climatic conditions of the area where the plant was grown and its vegetative stage, harvest age and fraction used (leaves, stems or stem + leaves, pulp, whole fruit) (Brito et al. 2005; Arruda et al. 2010).

Therefore, considering the factors inherent to feedstuffs and the constant genetic evolution of poultry farming, it is necessary to determine the nutritional values of ingredients used in the formulation of diets for those animals (Rodrigues et al. 2001; Nunes 2003; Carvalho 2004; Sakomura et al. 2004b, Nery 2007; Brumano 2006).

The choice of which feedstuffs to use in the formulation of broiler diets depends on detailed knowledge of their chemical composition, viability of inclusion and intended inclusion levels (Mutayoba et al. 2011; Ebenebe et al. 2013; Gadziraya et al. 2012), as well as how the nutrients will be utilized through the different animal life stages (Santos et al. 2012).

Brazil has a great diversity of plant-based foods and derived products that can be used in animal feeding. Moringa and bocaiuva are noteworthy examples of such alternatives found in the country. The nutritional characteristics of moringa leaf meal make it a great option as an alternative to soybean meal in animal nutrition (Macambira et al. 2016), as it is high in protein, has a good essential amino acid composition and contains insignificant amounts of antinutritional compounds (Makkar et al. 1996; Ferreira et al. 2008).

Bocaiuva is considered an alternative for inclusion in poultry diets as a substitute for corn due to its high yield, which can exceed 30 t/ha (Moreira and Sousa 2009), as well as nutritional composition (Ramos et al. 2008).

The conflicting results found in the literature and the scarcity of research illustrating the utilization of energy and the metabolizability of nutrients from alternative ingredients used in 
the diets of slow-growing broilers at different ages indicate the need for metabolism studies, considering that these birds have a different growth rate compared to industrial birds. As a consequence, diets are formulated with nutritional data from composition tables determined using fast-growing lines.

Few studies have examined the use of moringa leaf meal and bocaiuva pulp in the diets of slow-growing broilers. Thus, the present study proposes to determine the nutrient metabolizability coefficients and the apparent metabolizable energy and nitrogen-corrected apparent metabolizable energy values of moringa leaf meal and bocaiuva pulp for slow-growing broilers at different ages.

\section{Material and Methods}

\subsection{Birds, Experimental Design and Husbandry}

The experimental procedures described herein were approved by the Ethics Committee on Animal Use (CEUA) (approval no. 977/2018).

Three hundred and fifty 1-day-old male chicks of the Red Naked Neck line were allocated to five treatments in a completely randomized design with seven replicates and ten birds per experimental unit. Birds were housed in metabolic cages $(60 \times 80 \times 42 \mathrm{~cm})$ equipped with a trough-type feeder, a nipple-type drinker and a tray for excreta collection. The total excreta collection methodology was employed, following Sakomura and Rostagno (2016).

The composition of the main ingredients used in the diets is shown in Table 1. The treatments consisted of a corn- and soybean meal-based control diet formulated to meet the nutritional requirements of brown-egg replacement layers, according to Rostagno et al. (2017) (Table 2); a test diet composed of $80 \%$ of control diet $+20 \%$ moringa leaf meal (dried and ground leaves of moringa); a test diet composed of $80 \%$ of control diet $+20 \%$ bocaiuva meal (waste post oil extraction); a test diet composed of $60 \%$ of control diet $+40 \%$ corn; and a test diet composed of $60 \%$ of control diet $+40 \%$ soybean meal. Feed and water were available $a d$ libitum.

\subsection{Determination of Metabolizable Energy}

The trials were conducted in the periods of 19 to 26 (starter phase), 47 to 54 (grower phase) and 69 to 76 (finisher phase) days of age. Each period consisted of three days of adaptation to the experimental diets and five days of excreta collection. In the periods when no metabolizability trial was undergoing, all birds were fed control diet. During the experiment, mortality, maximum and minimum temperatures and relative air humidity were recorded at $07 \mathrm{~h} 00$ and $17 \mathrm{~h} 00$.

Table 1. Chemical composition and gross energy values of the ingredients, on a dry matter 
basis

\begin{tabular}{lcccc} 
Nutrient & $\begin{array}{c}\text { Moringa leaf } \\
\text { meal }\end{array}$ & Bocaiuva pulp & Corn & Soybean meal \\
\hline $\mathrm{DM}(\mathrm{g} / 100 \mathrm{~g})$ & 89.63 & 92.47 & 90.04 & 91.64 \\
$\mathrm{CP}(\mathrm{g} / 100 \mathrm{~g})$ & 15.02 & 3.97 & 7.06 & 43.48 \\
$\mathrm{CF}(\mathrm{g} / 100 \mathrm{~g})$ & 10.17 & 7.93 & 0.81 & 0.70 \\
$\mathrm{NDF}(\mathrm{g} / 100 \mathrm{~g})$ & 21.67 & 35.55 & 8.48 & 17.54 \\
$\mathrm{ADF}(\mathrm{g} / 100 \mathrm{~g})$ & 16.47 & 28.33 & 3.22 & 5.76 \\
$\mathrm{EE}(\mathrm{g} / 100 \mathrm{~g})$ & 3.21 & 12.64 & 3.00 & 1.78 \\
$\mathrm{MM}(\mathrm{g} / 100 \mathrm{~g})$ & 12.50 & 5.08 & 1.08 & 6.28 \\
$\mathrm{GE}(\mathrm{MJ} / \mathrm{kg})$ & 15.82 & 19.27 & 16.50 & 17.89 \\
\hline
\end{tabular}

Ferric oxide (1\%) was added to the diets as a marker to establish the start and end of the excreta collection period. Excreta were collected twice daily, at $08 \mathrm{~h} 00$ and $16 \mathrm{~h} 00$. In all trials, the amount of feed supplied and orts at the end of the collection period were weighed to determine total feed intake. At the end of each collection, excreta were packed in plastic bags, which were labeled per treatment and replicate, and immediately frozen for later analyses. Samples of feed and ingredients were stored for later analyses.

\subsection{Analysis}

At the end of the collections, all excreta samples corresponding to each experimental unit and rearing phase were thawed, weighed and homogenized. Samples were pre-dried in a forced-air oven $\left(55^{\circ} \mathrm{C}\right)$ for $72 \mathrm{~h}$ and then processed through a knife mill with 1-mm sieves to obtain a finely ground material, which was placed in plastic containers for analyses of dry matter (DM), ether extract (EE) and nitrogen (N), following Silva and Queiroz (2002).

The metabolizability coefficients of dry matter (MCDM), crude protein (MCCP) and ether extract (MCEE) and the apparent metabolizable energy (AME) and nitrogen-corrected AME (AMEn) values were determined using equations proposed by Matterson et al. (1965).

\subsection{Statistical Analysis}

Data were subjected to analysis of variance and means were compared by Tukey's test at the $5 \%$ probability level using SAS 9.0 statistical software.

Table 2. Centesimal composition and calculated values of control diet for slow-growing 
broilers

\begin{tabular}{|c|c|c|c|}
\hline \multirow[b]{2}{*}{ Ingredient (g/100 g) } & \multicolumn{3}{|c|}{ Rearing phase } \\
\hline & $\begin{array}{c}\text { Starter } \\
\text { (19 to } 26 \\
\text { days) }\end{array}$ & $\begin{array}{c}\text { Grower } \\
\text { (47 to } 54 \\
\text { days) }\end{array}$ & $\begin{array}{c}\text { Finisher } \\
\text { (69 to } 76 \\
\text { days) }\end{array}$ \\
\hline Corn $(7.88 \%)$ & 59.44 & 63.23 & 72.63 \\
\hline Soybean meal (46\%) & 34.41 & 30.71 & 24.33 \\
\hline Soybean oil & 0.05 & 0.05 & - \\
\hline Inert & 2.28 & 1.93 & - \\
\hline Dicalcium phosphate & 1.79 & 1.80 & 1.62 \\
\hline Limestone & 1.00 & 0.98 & 0.91 \\
\hline Salt & 0.42 & 0.38 & 0.35 \\
\hline DL-methionine & 0.27 & 0.24 & - \\
\hline L-lysine $\mathrm{HCl}$ & 0.13 & 0.07 & - \\
\hline L-threonine & 0.05 & 0.02 & - \\
\hline Vitamin supplement ${ }^{1}$ & 0.10 & 0.10 & 0.10 \\
\hline \multirow[t]{2}{*}{ Mineral supplement $^{2}$} & 0.05 & 0.05 & 0.05 \\
\hline & \multicolumn{3}{|c|}{ Calculated values } \\
\hline Metabolizable energy (Kcal/kg) & 2,850 & 2,850 & 3,004 \\
\hline Crude protein $(\mathrm{g} / 100 \mathrm{~g})$ & 20.98 & 19.50 & 17.05 \\
\hline $\begin{array}{l}\text { Dig. methionine + cysteine }(\mathrm{g} / 100 \\
\text { g) }\end{array}$ & 0.84 & 0.77 & 0.48 \\
\hline Dig. lysine (g/100 g) & 1.14 & 0.96 & 0.76 \\
\hline Dig. threonine (g/100 g) & 0.76 & 0.68 & 0.58 \\
\hline Calcium (g/100 g) & 0.95 & 0.93 & 0.84 \\
\hline Av. phosphorus (g/100 g) & 0.44 & 0.43 & 0.39 \\
\hline Sodium $(g / 100 \mathrm{~g})$ & 0.18 & 0.17 & 0.16 \\
\hline
\end{tabular}

${ }^{1}$ Mineral supplement (provides per $\mathrm{kg}$ of diet): $11.00 \mathrm{mg}$ zinc; $3.04 \mathrm{mg}$ pantothenic acid; 0.22 $\mathrm{mg}$ iodine; $0.06 \mathrm{mg}$ selenium; $90.3 \mathrm{mg}$ choline; $8.48 \mathrm{mg}$ iron; $2.64 \mathrm{mg}$ copper; $15.15 \mathrm{mg}$ manganese. ${ }^{2}$ Vitamin supplement (provides per $\mathrm{kg}$ of diet): 2,400 IU vitamin A; $480 \mathrm{IU}$ vitamin D3; $0.32 \mathrm{mg}$ vitamin $\mathrm{K} 3 ; 0.51 \mathrm{mg}$ vitamin $\mathrm{B} 1 ; 1.38 \mathrm{mg}$ vitamin $\mathrm{B} 2 ; 0.64 \mathrm{mg}$ vitamin B6; $2.88 \mathrm{mg}$ vitamin $\mathrm{B} 12 ; 3.00 \mathrm{mg}$ vitamin $\mathrm{E} ; 7.12 \mathrm{mg}$ niacin.

\section{Results}




\subsection{Environment}

Mean values of maximum and minimum temperatures and relative humidity in the experimental period varied from 25.3 to $32.9{ }^{\circ} \mathrm{C}$ and 45.8 to $69.3 \%$ in the starter phase (19 to 26 days); 22.7 to $29.9^{\circ} \mathrm{C}$ and 54.2 to $72.3 \%$ in the grower phase (47 to 54 days); and 22.2 to $27.3{ }^{\circ} \mathrm{C}$ and 62.4 to $75.1 \%$ in the finisher phase (69 to 76 days). The birds were found to be under moderate heat stress in the grower and finisher phases.

\subsection{Metabolizability Coefficients}

In the period of 19 to 26 days of age, the highest MCDM $(\mathrm{P}<0.05)$ was found with corn, whereas the lowest $(\mathrm{P}<0.05)$ was found with moringa leaf meal and intermediate values were obtained with bocaiuva pulp and soybean meal (Table 3). The MCCP of bocaiuva pulp was higher $(\mathrm{P}<0.05)$ than that of soybean meal and similar $(\mathrm{P}>0.05)$ to those found with corn and moringa leaf meal. Bocaiuva pulp showed the highest $(\mathrm{P}<0.05) \mathrm{MCEE}$, and the MCEE of corn and soybean meal were similar $(\mathrm{P}>0.05)$.

Table 3. Metabolizability coefficients of moringa leaf meal, bocaiuva pulp, corn and soybean meal for slow-growing broilers at different ages

\begin{tabular}{|c|c|c|c|c|c|c|}
\hline \multicolumn{7}{|c|}{19 to 26 days } \\
\hline Variable $(\mathrm{g} / 100 \mathrm{~g})$ & Moringa leaf meal & Bocaiuva pulp & Corn & Soybean meal & $\mathrm{CV}(\%)$ & P-value \\
\hline Dry matter & $65.59^{\mathrm{b}}$ & $65.85^{\mathrm{ab}}$ & $65.87^{\mathrm{a}}$ & $65.68^{\mathrm{ab}}$ & 0.30 & 0.0392 \\
\hline Crude protein & $60.91^{\mathrm{ab}}$ & $61.28^{\mathrm{a}}$ & $61.11^{\mathrm{ab}}$ & $60.77^{\mathrm{b}}$ & 0.44 & 0.0096 \\
\hline Ether extract & $84.65^{\mathrm{c}}$ & $85.59^{\mathrm{a}}$ & $84.99^{\mathrm{b}}$ & $85.15^{\mathrm{b}}$ & 0.22 & $<0.0001$ \\
\hline \multicolumn{7}{|c|}{47 to 54 days } \\
\hline Variable $(\mathrm{g} / 100 \mathrm{~g})$ & Moringa leaf meal & Bocaiuva pulp & Corn & Soybean meal & $\mathrm{CV}(\%)$ & P-value \\
\hline Dry matter & $60.10^{\mathrm{c}}$ & $60.67^{\mathrm{b}}$ & $61.05^{\mathrm{a}}$ & $60.49^{\mathrm{b}}$ & 0.42 & $<0.0001$ \\
\hline Crude protein & $54.58^{\mathrm{a}}$ & $54.84^{\mathrm{a}}$ & $54.69^{\mathrm{a}}$ & $54.20^{\mathrm{b}}$ & 0.40 & $<0.0001$ \\
\hline Ether extract & $72.05^{\mathrm{bc}}$ & $72.88^{\mathrm{a}}$ & $71.96^{\mathrm{c}}$ & $72.15^{\mathrm{b}}$ & 0.15 & $<0.0001$ \\
\hline \multicolumn{7}{|c|}{69 to 76 days } \\
\hline Variable $(\mathrm{g} / 100 \mathrm{~g})$ & Moringa leaf meal & Bocaiuva pulp & Corn & Soybean meal & $\mathrm{CV}(\%)$ & P-value \\
\hline Dry matter & $79.72^{\mathrm{b}}$ & $79.87^{\mathrm{b}}$ & $80.32^{\mathrm{a}}$ & $79.76^{\mathrm{b}}$ & 0.30 & $<0.0001$ \\
\hline Crude protein & 58.96 & 58.99 & 58.98 & 58.60 & 0.48 & 0.0507 \\
\hline Ether extract & $73.40^{\mathrm{ab}}$ & $73.63^{\mathrm{a}}$ & $73.09^{b}$ & $73.13^{b}$ & 0.45 & 0.0192 \\
\hline
\end{tabular}

Means followed by common letters in the same row do not differ according to Tukey's test.

From 47 to 54 days of age, a significant difference was detected $(\mathrm{P}<0.05)$ for MCDM, MCCP and MCEE. The highest and lowest $(\mathrm{P}<0.05) \mathrm{MCDM}$ were found for corn and moringa leaf meal, respectively. The MCDM of bocaiuva pulp and soybean meal were similar $(\mathrm{P}>0.05)$. The MCCP of moringa leaf meal, bocaiuva pulp and corn were also similar $(\mathrm{P}>0.05)$, whereas that of soybean meal was the lowest. Bocaiuva pulp exhibited the highest $(\mathrm{P}<0.05)$ MCEE, while the MCEE of moringa leaf meal was similar $(\mathrm{P}>0.05)$ to those of corn and soybean meal.

In the period of 69 to 76 days, a significant difference was detected $(\mathrm{P}<0.05)$ for MCDM and 
MCEE. The highest $(\mathrm{P}<0.05) \mathrm{MCDM}$ was found for corn, whereas lower values were found for moringa leaf meal, bocaiuva pulp and soybean meal. There were no significant differences $(\mathrm{P}>0.05)$ for the metabolizability of $\mathrm{CP}$ between the different feedstuffs. Bocaiuva pulp showed a higher $(\mathrm{P}<0.05)$ MCEE. Corn and soybean meal exhibited a lower $(\mathrm{P}<0.05)$ MCEE; however, the MCEE of moringa leaf meal was similar $(\mathrm{P}>0.05)$ to those of bocaiuva, corn and soybean meal.

\subsection{Metabolizable Energy}

Significant differences were recorded $(\mathrm{P}<0.05)$ for the AME and AMEn values at the different ages (Table 4). The AME of corn and soybean meal were higher $(\mathrm{P}<0.05)$ and similar to each other $(\mathrm{P}>0.05)$ in the period of 19 to 26 days of age. The alternative feedstuffs showed the lowest $(\mathrm{P}<0.05)$ AME values, which were similar $(\mathrm{P}>0.05)$ to each other. The AMEn values of corn and soybean meal were similar $(\mathrm{P}>0.05)$. Moringa leaf meal showed a lower $(\mathrm{P}<0.05)$ AMEn value; however, the AMEn value of bocaiuva pulp was similar $(\mathrm{P}>0.05)$ to that of moringa leaf meal and soybean meal.

Table 4. Apparent metabolizable energy (AME) and nitrogen-corrected apparent metabolizable energy (AMEn) of moringa leaf meal, bocaiuva pulp, corn and soybean meal for slow-growing broilers at different ages

\begin{tabular}{|c|c|c|c|c|c|c|}
\hline \multicolumn{7}{|c|}{19 to 26 days } \\
\hline $\begin{array}{l}\text { Variable } \\
\text { (Kcal/kg) }\end{array}$ & $\begin{array}{l}\text { Moringa } \\
\text { leaf meal }\end{array}$ & $\begin{array}{c}\text { Bocaiuva } \\
\text { pulp }\end{array}$ & Corn & $\begin{array}{c}\text { Soybean } \\
\text { meal }\end{array}$ & $\mathrm{CV}(\%)$ & P-value \\
\hline $\mathrm{AME}$ & $2557^{\mathrm{b}}$ & $2680^{\mathrm{b}}$ & $3581^{\mathrm{a}}$ & $3603^{a}$ & 15.97 & $<0.0001$ \\
\hline AMEn & $2205^{c}$ & $2483^{b c}$ & $3379^{a}$ & $2864^{\mathrm{ab}}$ & 15.97 & $<0.0001$ \\
\hline \multicolumn{7}{|c|}{47 to 54 days } \\
\hline $\begin{array}{l}\text { Variable } \\
\text { (Kcal/kg) }\end{array}$ & $\begin{array}{l}\text { Moringa } \\
\text { leaf meal }\end{array}$ & $\begin{array}{c}\text { Bocaiuva } \\
\text { pulp }\end{array}$ & Corn & $\begin{array}{c}\text { Soybean } \\
\text { meal }\end{array}$ & $\mathrm{CV}(\%)$ & P-value \\
\hline $\mathrm{AME}$ & $1461^{\mathrm{c}}$ & $2714^{\mathrm{b}}$ & $3591^{\mathrm{a}}$ & $2590^{\mathrm{b}}$ & 10.56 & $<0.0001$ \\
\hline AMEn & $1322^{\mathrm{c}}$ & $1730^{\mathrm{bc}}$ & $3178^{a}$ & $2228^{\mathrm{b}}$ & 10.56 & $<0.0001$ \\
\hline \multicolumn{7}{|c|}{69 to 76 days } \\
\hline $\begin{array}{l}\text { Variable } \\
\text { (Kcal/kg) }\end{array}$ & $\begin{array}{l}\text { Moringa } \\
\text { leaf meal }\end{array}$ & $\begin{array}{c}\text { Bocaiuva } \\
\text { pulp }\end{array}$ & Corn & $\begin{array}{c}\text { Soybean } \\
\text { meal }\end{array}$ & $\mathrm{CV}(\%)$ & P-value \\
\hline $\mathrm{AME}$ & $2868^{\mathrm{b}}$ & $3119^{b}$ & $4044^{\mathrm{a}}$ & $3118^{b}$ & 14.35 & $<0.0001$ \\
\hline AMEn & $2479^{b}$ & $2490^{\mathrm{b}}$ & $3887^{\mathrm{a}}$ & $2427^{b}$ & 14.35 & $<0.0001$ \\
\hline
\end{tabular}

Means followed by common letters in the same row do not differ according to Tukey's test $(\mathrm{P}<0.05)$.

In the period of 47 to 54 days of age, corn showed the highest $(\mathrm{P}<0.05)$ AME and AMEn values. The AME values of bocaiuva pulp and soybean meal were similar $(\mathrm{P}>0.05)$, whereas moringa leaf meal exhibited the lowest $(\mathrm{P}<0.05)$ AME value. The AMEn value of bocaiuva pulp was similar $(\mathrm{P}>0.05)$ to that of moringa leaf meal and soybean meal.

From 69 to 76 days of age, the highest $(\mathrm{P}<0.05)$ AME and AMEn values were found with 
corn. The AME and AMEn values of moringa leaf meal, bocaiuva pulp and soybean meal were similar $(\mathrm{P}>0.05)$.

\section{Discussion}

Several factors influence the metabolizability of nutrients from broiler diets, e.g., feed particle size and processing, bird age and sex, rearing environment and chemical composition of the dietary ingredients.

The chemical composition of moringa leaf meal, bocaiuva pulp, corn and soybean meal is highly variable across studies. The nutritional value of those feedstuffs is related to their chemical composition, soil-climatic conditions of the area where the plant was grown, plant vegetative stage and harvest age, and the fraction used (leaves, stem or stem + leaves, pulp, whole fruit) in the making of the meal or flour (Brito et al. 2005; Arruda et al. 2010). These variations in chemical composition imply differences in the nutrient metabolizability coefficients and AME and AMEn values of the feedstuffs.

The chemical composition of the moringa leaf meal evaluated in the present study $(89.63 \%$ DM, $15.02 \% \mathrm{CP}, 3.21 \% \mathrm{EE}, 12.50 \% \mathrm{MM}$ and $3781 \mathrm{Kcal} / \mathrm{kg} \mathrm{GE}$ ) revealed lower values than that determined by Macambira (2016), who found $90.17 \%$ DM, $18.31 \%$ CP, $8.65 \% \mathrm{EE}$, $11.10 \% \mathrm{MM}$ and $4526 \mathrm{Kcal} / \mathrm{kg}$ GE in the ingredient.

As regards the chemical and energy composition of bocaiuva pulp, a slight variation was observed for the CP, EE and MM levels in relation to literature descriptions. Similar DM and GE values were reported by Almeida (1998): $91.3 \%$ and $4632 \mathrm{Kcal} / \mathrm{kg}$, respectively. However, that author observed values lower than those obtained in the current study for CP, EE and MM (2.65, 8.46 and $3.45 \%$, respectively).

Variations were also observed in the chemical and energy composition of corn and soybean meal compared to literature descriptions. Nutrient and energy levels lower than those found in the current experiment were reported by Rostagno et al. (2017), i.e., $88.1 \%$ DM, $44.4 \%$ CP, $0.52 \% \mathrm{EE}, 5.19 \% \mathrm{MM}$ and 4,051 Kcal/kg GE in soybean meal; and $87.0 \% \mathrm{DM}, 6.92 \% \mathrm{CP}$, $3.22 \% \mathrm{EE}, 0.94 \% \mathrm{MM}$ and 3,865 Kcal/kg GE in corn. However, those values were obtained with fast-growing broilers.

Values lower than those reported in the present study were observed by Santos et al. (2012), who found $89.62 \% \mathrm{DM}, 8.41 \% \mathrm{CP}, 4.64 \% \mathrm{EE}, 1.20 \% \mathrm{MM}$ and $3947 \mathrm{Kcal} / \mathrm{kg}$ GE in corn. Ramos (2012), on the other hand, observed 88.50\% DM, 47.70\% CP, 3.24\% EE, $6.51 \% \mathrm{MM}$ and $4267 \mathrm{Kcal} / \mathrm{kg} \mathrm{GE}$ in soybean meal, which are similar to the present findings.

With respect to the minimum and maximum temperature and relative humidity means, the birds were found to be under moderate heat stress, especially in the grower phase. The thermal comfort zone varies according to age: in the first seven days of age, it is $32^{\circ} \mathrm{C}$; from the 8th to the 14 th day, $29^{\circ} \mathrm{C}$; from the 15 th to the 21 st day, $26^{\circ} \mathrm{C}$; and from the 22 nd to the 30th day of age, $23{ }^{\circ} \mathrm{C}$ (Globoaves 2015).

After the period of maturation of the thermoregulatory system, the chicken, like other homeothermic animals, maintains its body temperature constant over variations in the 
environment. However, when the physiological and behavioral responses to high temperatures are inadequate, body temperature increases (Yahav et al. 1998) and, in an attempt to mitigate this increase in body temperature, broilers minimize endogenous heat production by reducing their intake, which then leads to a decrease in nutrient and energy metabolizability (Yahav et al. 2005; Welker et al. 2008).

The observed MCDM and MCCP of moringa leaf meal were lower than those reported by Macambira et al. (2018), who found the respective values of $76.8 \pm 6.6$ and $71.7 \pm 7.3$ in fast-growing broilers (Cobb 500) at 14 days of age. Slow-growing broilers may exhibit different nutrient utilization patterns due to a lower growth rate associated with the formation of digestive organs and enzyme production, which occur at a different rhythm when compared to fast-growing birds

The MCDM, MCCP and MCEE of corn obtained in the present experiment from 19 to 26 days of age were lower than the $88.99,88.19$ and $92.29 \%$, respectively, reported by Santos (2012). Those authors also observed higher MCDM, MCCP and MCEE in soybean meal: 49.7, 71.45 and 46.74\%, respectively, in slow and fast-growing broilers (Isa Label and Cobb lines) at different ages.

Of the metabolizability coefficients determined in this study (MCDM, MCCP and MCEE), MCCP was the lowest $(\mathrm{P}<0.05)$ in all evaluated feedstuffs. The presence of antinutritional factors such as dietary fiber components, phenolic compounds an enzyme inhibitors modify digestion and chemical reactions, thereby altering the release of amino acids and proteins through enzymatic processes (Hiane 2006). The presence of fiber, especially structural polysaccharides of cell walls and their interactions with protein, may reduce the accessibility of protein to proteolysis, reducing its metabolizability (Melito and Tovar 1995; Galland-Irmouli et al. 1999).

The AME and AMEn values of moringa leaf meal, bocaiuva pulp, corn and soybean meal were higher when determined in older birds. This assertion is corroborated by the findings of Batal and Parsons (2002), Sakomura et al. (2004), Mello et al. (2009) and Santos et al. (2012). A linear increase in pancreatic amylase, trypsin and lipase with the advance of age was observed by Sakomura et al. (2004). In their study, the greatest increase was observed in the second week of age, which coincides with the period of greatest digestive enzyme activity, demonstrating that the older the bird is, the better the utilization of dietary energy.

The AME values of moringa leaf meal were lower than the $2978 \mathrm{Kcal} / \mathrm{kg}$ and $2725 \mathrm{Kcal} / \mathrm{kg}$ described by Olugbemi et al. (2010) and Nkakwana et al. (2014), respectively.

The current AME and AMEn results for corn and soybean meal differ from those reported by Mello et al. (2009), who measured those variables in corn in broilers in the periods of 10 to 17 days (starter phase), 26 to 33 days (grower phase) and 40 to 47 days of age (finisher phase). The said authors found AME and AMEn values of 3167 and $3168 \mathrm{Kcal} / \mathrm{kg}$ in the starter phase, 3144 and $3135 \mathrm{Kcal} / \mathrm{kg}$ in the grower phase and 3390 and $3389 \mathrm{Kcal} / \mathrm{kg}$ in the finisher phase, respectively. These results are lower than those obtained in the present study, which may be explained by the fact that those authors used fast-growing lines, whose rearing 
phases are different from those of slow-growing lines. Likewise, the above-mentioned authors found lower AME and AMEn values with soybean meal: 1759 and $1748 \mathrm{Kcal} / \mathrm{kg}$ in the starter phase, 2206 and $2192 \mathrm{Kcal} / \mathrm{kg}$ in the grower phase and 2247 and $2296 \mathrm{kcal} / \mathrm{kg}$ in the finisher phase, respectively.

Overall, in view of the existing differences in growth rate between lines and variations in the AME and AMEn coefficients between the feedstuffs evaluated at different ages, further studies are warranted to investigate the metabolizability of ingredients used in the formulation of diets for slow-growing broilers so that food composition tables can be improved with energy values determined according to the bird's age.

In this context, it is concluded that AME and AMEn values of moringa leaf meal range between 2557 and $2868 \mathrm{Kcal} / \mathrm{kg}$ and 2205 and $2479 \mathrm{Kcal} / \mathrm{kg}$, respectively, while the AME and AMEn values of bocaiuva pulp vary from 2680 to $3119 \mathrm{Kcal} / \mathrm{kg}$ and 2483 to 2490 $\mathrm{Kcal} / \mathrm{kg}$, respectively.

The alternative ingredients can thus be used in the formulation of diets for slow-growing broilers to partially replace corn and soybean meal.

\section{Acknowledgments}

The authors thank the Ministry of Science and Technology of Mozambique for the fellowship grant and the support of Federal University of Mato Grosso do Sul. The present study was supported by the Coordination for the of Improvement Higher Education Personnel - Brazil (CAPES) - Finance code 001.

\section{References}

Almeida, S. P. (1998). Cerrado: Aproveitamento alimentar, Planaltina: EMBRAPA-CPAC. p.188.

Arruda, A. M. V., Fernandes, R. T. V., Oliveira, J. F., Filgueira, T. M. B., Fernandes, D. R., \& Galvão, R. J. D. (2010). Valor energético de fenos de forrageiras do semi-árido para aves Isa Label. Acta Veterinária Brasílica, (4), 105-112. https://doi.org/10.21708/avb.2010.4.2.1539

Brito, A. B., Stringhini, J. H., Cruz, C. P., Xavier, S. A. G., Silva, L. A. F., Café, M. B., \& Leandro N. S. M. (2005). Avaliação nutricional do gérmen integral de milho para aves. Ciência Animal Brasileira, (6), 19-26. Available in: https://www.revistas.ufg.br/vet/article/view/348/323, Access in: January 14, 2020

Brumano, G., Gomes, P. C., Albino, L. F. T., Rostagno, H. S., Generoso, R. A. R., \& Schmidt, M. (2006). Composição química e valores de energia metabolizável de alimentos proteicos determinados com frangos de corte em diferentes idades. Revista Brasileira de Zootecnia, (6), 2297-2302. https://doi.org/10.1590/S1516-35982006000800014

Carvalho, D. C. O., Albino, L. F. T., Rostagno, H. S., Oliveira, J. E., Vargas Jr, J. G., Toleto, R. S., ... Souza, R. M. S. (2004). Composição química e energética de amostras de milho submetidas a diferentes temperaturas de secagem e períodos de armazenamento. Revista 
Brasileira de Zootecnia, (2), 358-364. https://doi.org/10.1590/S1516-35982004000200012

Ebenebe, C. I., Anigbogu. C. C., Anizoba, M. A., \& Ufele, A. N. (2013). Effect of various levels of moringa leaf meal on the egg quality of Isa Brown breed of layers. Advances in Life Science and Technology, (14), 45-49. Available in: https://iiste.org/Journals/index.php/ALST/article/viewFile/8612/8809. Access in January 14, 2020

Ferreira, P. M. P., Farias, D. F., Oliveira, J. T. A., \& Carvalho, A. F. U. (2008). Moringa oleífera: bioactive compounds and nutritional potencial. Revista de Nutrição, (4), 431-437. https://doi.org/10.1590/S1415-52732008000400007

Gadzirayi, C. T., Massamha, B., Mupangwa, J. F., \& Washaya, S. (2012). Performance of broiler chickens feed moringa oleifera leaf meal as a protein supplement to soybean meal. International Journal Poultry Science, (11), 5-10. https://doi.org/10.3923/ijps.2012.5.10

Galland-Irmouli, A. V., Fleurence, J., Lamghary, R., Lucon, M., Rouxel, C., Barbaroux, O., ... Gueant, J. L. (1999). Nutritional value of proteins from edible seaweed, Palmaria palmata (Dulse). Journal Nutrition Biochemistry, (10), 353-359. https://doi.org/10.1016/S0955-2863(99)00014-5

Generoso, R. A. R., Gomes, P. C., Rostagno, H. S., Albino, F. T., Barreto, L. T., \& Brumano, G. (2008). Composição química e energética de alguns alimentos para frangos de corte em duas idades. Revista Brasileira de Zootecnia, (7), 1251-1256. https://doi.org/10.1590/S1516-35982008000700016

Globoaves. (2011). Manual de manejo linha colonial. Globoaves. p.20.

Hiane, P. A., Baldasso, P. A., Marangoni, S., \& Macedo., M. L. R. (2006). Chemical and nutritional evaluation of kernels of bocaiúva Acrocomia aculeata (Jacq.) Lodd. Ciência e Tecnologia de Alimentos, 26(3),683-689. https://doi.org/10.1590/S0101-20612006000300031

Macambira, G. M. (2016). Uso da farinha de folhas de moringa oleífera na alimentação de frangos de corte. Dissertação (Mestrado em Zootecnia). Universidade Federal Rural de Pernambuco. Recife, Pernambuco. Available in: http://www.tede2.ufrpe.br:8080/tede2/bitstream/tede2/6962/2/Gabriel\%20Miranda\%20Maca mbira.pdf. Access in: January 16, 2020

Macambira, G. M., Rabello, C. B. V., Navarro, M. C. M. M., Ludke, J. C. R., Silva, E. C., Lopes, G. R. N., ... Silva, D. A. (2018). Caracterização nutricional das folhas de Moringa Oleifera (MOL) para frangos de corte. Arquivos Brasileiros de Medicina Veterinária e Zootecnia, (70), 570-578. https://doi.org/10.1590/1678-4162-9522

Makkar, H. P. S., \& Becker, K. (1996). Nutritional value and antinutritional components of whole and ethanol extracted Moringa oleifera leaves. Animal Feed Science and Technology, (63), 211-228. https://doi.org/10.1016/S0377-8401(96)01023-1

Matterson, L. D., Potter, L. M., Stutz, M. W., \& Singsen, E. P. (1965). The metabolizable energy of feed ingredients for chickens. Storrs: University of Connecticut Storrs, (11), 3-11. 
(Agricultural Experiment Station Research Report).

Melito, C., \& Tovar, J. (1995). Cell walls limit in vitro protein digestibility in processed legume seed. Food Chemistry, (53) 305-307. https://doi.org/10.1016/0308-8146(95)93937-M

Mello, H. H. C., Gomes, P. C., Rostagno, H. S., Albino, L. F. T., Souza, R. M., \& Calderano, A. A. (2009). Valores de energia metabolizável de alguns alimentos obtidos com aves de diferentes idades. Revista Brasileira de Zootecnia, (5), 863-868. https://doi.org/10.1590/S1516-35982009000500012

Moreira, J. M. M. A. P., \& Sousa, T. C. R. (2009). Macaúba: oportunidades e desafios. Planaltina, DF: Embrapa Cerrados. Avaliable in: http://www.cpac.embrapa.br/noticias/artigosmidia/publicados/163/ Access in: January 14, 2020.

Mutayoba, S. K., Dierenfeld, E., Mercedes, V. A., Frances, Y., \& Knight, C. D. (2011). Determination of chemical composition and ant-nutritive components for Tanzanian locally available poultry feed ingredients. International Journal of Poultry Science, 10, 350-357. https://doi.org/10.3923/ijps.2011.350.357

Nery, L.R., Albino, L.F.T., Rostagno, H.S., Campos, A.M.A \& Silva, C.R. (2007). Valores de energia metabolizável de alimentos determinados com frangos de corte. Revista Brasileira de Zootecnia, (5), 1354-1358. https://doi.org/10.1590/S1516-35982007000600018

Nkakwana, T. T., Muchenje, V., Pieterse, E., Masika, P. J., Mabusela, T. P., Hoffman, L. C., \& Dzima, K. (2014). Effect on Moringa oleifera Leaf Meal on Growth Performance, Apparent Digestibility, Digestive Organ Size and Carcass Yield in Broiler Chickens. Livestock Science, (161), 139-146. https://doi.org/10.1016/j.livsci.2014.01.001

Nunes, R. V., Rostagno, H. S., Albino, L. F. T., Gomes, P. C., \& Toledo, R. S. (2003). Composição bromatológica, energia metabolizável e equações de predição da energia do grão e de subprodutos do trigo para pintos de corte. Revista Brasileira de Zootecnia, (3), 785-793. https://doi.org/10.1590/S1516-35982001000300025

Olugbemi, T. S., Mutayoba, S. K., \& Lekule, F. P. (2010). Evaluation of Moringa oleifera leaf meal inclusion in cassava chip diets fed to laying birds. Livestock Research for Rural Development, 22(6), 118.

Ramos, M. I. L., Ramos Filho, M. M., Hiane, P. A., Braga Neto, J. A., \& Siqueira, E. M. A. (2008). Qualidade nutricional da polpa de bocaiúva Acrocomia aculeata (Jacq Lodd). Ciência e Tecnologia de Alimentos, Campinas, $\quad$ (28), 90-94. https://doi.org/10.1590/S0101-20612008000500015

Rodrigues, P. B., Rostagno, H. S., Albino, L. F. T., Gomes, P. C., Barboza, W. A., \& Santana, R. T. (2001). Valores energéticos do milheto, do milho e subprodutos do milho, determinados com frangos de corte e galos adultos. Revista Brasileira de Zootecnia, (6), 1767-1778. https://doi.org/10.1590/S1516-35982001000700015

Rostagno, H. S., Albino, L. F. T., Hannas, N. I., Donzele, J. L., Sakomura, N. K., Perazzo, F. 


\section{Macrothink}

Journal of Agricultural Studies

ISSN 2166-0379

2020, Vol. 8, No. 3

G, ... Brito, C. O. (2017). Tabelas brasileiras para aves e suínos - composição de alimentos e exigências nutricionais. (4ed). Viçosa: UFV, p.488.

Sakomura, N. K., \& Rostagno, H. S. (2016). Metodologias para avaliar o conteúdo de energia dos alimentos, In: Métodos de Pesquisa em Nutrição de Monogástricos. (2ed). Jaboticabal: Funep, p.262.

Sakomura, N. K., Del Bianchi, M., Pizauro Jr, J. M., Café, M. B., \& Freitas, E. R. (2004). Efeito da idade dos frangos de corte sobre a atividade enzimática e digestibilidade dos nutrientes do farelo de soja e da soja integral. Revista Brasileira de Zootecnia, (4), 924-935. https://doi.org/10.1590/S1516-35982004000400013

Santos, F. R. (2012). Comparação da eficiência digestiva e metabolismo de nutrientes e de energia entre frangos de crescimento lento e rápido. Tese. Goiânia: UFG. p.100. Available in: https://ppgca.evz.ufg.br/up/67/o/Tese2012_Fabiana_Santos.pdf. Access in: January 14, 2020.

Silva, D. J., \& Queiroz, A. C. (2002). Análise de alimentos (métodos químicos e biológicos). (3ed). Viçosa: UFV, p.235.

Welker, J. S., Rosa, A. P., Moura, D. J., Machado, L. P., Catelan, F., \& Uttpatel, R. (2008). Temperatura corporal de frangos de corte em diferentes sistemas de climatização. Brazilian $\begin{array}{llll}\text { Journal of Animal } & \text { Science, } & 37(8), & 1.463-1.467 .\end{array}$ https://doi.org/10.1590/S1516-35982008000800018

Yahav, S., Luger, D., Cahaner, A., Dotan, M., Rusan, M., \& Hurwitz, S. (1998). Thermoregulation in naked neck chickens subjected to different ambient temperatures. Brazilian Poultry Science, (39), 133-138. https://doi.org/10.1080/00071669889510

Yahav, S., Shinder, D., Tanny, J., \& Cohen, S. (2005). Sensible heat loss: the broiler's paradox. World's Poultry Science Journal, Beekbergen, 61(3), 419-434. https://doi.org/10.1079/WPS200453

\section{Copyright Disclaimer}

Copyright for this article is retained by the author(s), with first publication rights granted to the journal.

This is an open-access article distributed under the terms and conditions of the Creative Commons Attribution license (http://creativecommons.org/licenses/by/4.0/). 